\title{
Microstructure and reaction mechanisms at $\gamma$-TiAl brazed interfaces
}

\author{
A. Guedes*, A. M. P. Pinto*, E. W. Sequeiros**, M. F. Vieira** and F. Viana**
}

*CT2M, Centre for Mechanical and Materials Technologies, University of Minho, Campus de Azurém, 4800-058 Guimarães, Portugal

**CEMUC@, Department of Metallurgical and Materials Engineering, University of Porto, R. Dr. Roberto Frias, 4200-465 Porto, Portugal

aguedes@dem.uminho.pt

Titanium aluminide alloys based on the $\gamma$-TiAl intermetallic compound are emerging as potential materials for high performance applications on aircraft engines components, aerospace vehicles and automotive engines, owing to their low density, high specific stiffness, excellent strength retention at high temperature and good creep and oxidation resistance [1]. The development of adequate techniques to join $\gamma$-TiAl alloys, either to themselves or to other materials, is a key issue regarding the effective use of these alloys [2,3]. Understanding of the reaction mechanisms that promote bonding is mandatory when optimization of the joining procedure is envisaged.

A detail study focussing the microstructural evolution of the interfacial zone in the course of the processing of $\mathrm{Ti}-47 \mathrm{Al}-2 \mathrm{Cr}-2 \mathrm{Nb}$ joints using a $\mathrm{Ti} /(\mathrm{Cu}, \mathrm{Ni}) / \mathrm{Ti}$ clad-laminated filler as brazing alloy was performed in this investigation. Joining was carried out in vacuum (better than $10^{-4} \mathrm{mbar}$ ) in the temperature range of 980 to $1200^{\circ} \mathrm{C}$ with a $10 \mathrm{~min}$. dwelling stage at the brazing temperature. Experiments were also performed below the solidus temperature of the filler, at 700,800 and $900^{\circ} \mathrm{C}$, aiming the understanding of the mechanisms that promote the melting of the braze alloy. The resulting interfaces were analysed by scanning electron microscopy (SEM) and by energy dispersive X-ray spectroscopy (EDS).

In the course of the heating stage, several reaction layers composed of $\mathrm{Ti}-\mathrm{Cu}-\mathrm{Ni}$ phases were formed within the filler alloy due to the atomic interdiffusion between the $(\mathrm{Cu}, \mathrm{Ni})$ and Ti foils (see Fig. 1). After heating to $900^{\circ} \mathrm{C}$, the microstructure of the brazing alloy evolved form the initial $\mathrm{Ti}(\alpha) /(\mathrm{Cu}, \mathrm{Ni}) / \mathrm{Ti}(\alpha)$ layers to a symmetrical multilayered microstructure consisting of $\mathrm{Ti}(\alpha) / \mathrm{Ti}(\alpha)+\mathrm{Ti}_{2} \mathrm{Cu} / \mathrm{Ti}_{2} \mathrm{Ni} / \mathrm{TiNi} / \mathrm{TiCuNi} /(\mathrm{Cu}, \mathrm{Ni})$ layers.

The results obtained from the experiments suggest that the filler begins to melt near $930^{\circ} \mathrm{C}$ due to the $\mathrm{Ti}_{2} \mathrm{Ni}+\mathrm{Ti}_{2} \mathrm{Cu} \rightarrow \mathrm{L}$ reaction [4], occurring between two adjacent layers that are composed, at room temperature, of $\mathrm{Ti}_{2} \mathrm{Ni}$ and $\mathrm{Ti}(\alpha)+\mathrm{Ti}_{2} \mathrm{Cu}$ (see Fig. 1c)). The liquid will then dissolve the neighbouring layers as it spreads simultaneously towards the centre and the periphery of the filler.

When the liquid reaches the $\gamma$-TiAl alloy surface, dissolution of the intermetallic alloy and diffusion of $\mathrm{Al}$ atoms across the interfacial zone became the determinant factors regarding the microstructural evolution of the interface. The resulting interfaces present a multilayered microstructure, which consists of three different reaction layers, composed of $\alpha_{2}-\mathrm{Ti} 3 \mathrm{Al}+\mathrm{Ti}(\mathrm{Cu}, \mathrm{Ni}) \mathrm{Al} / \alpha_{2}-\mathrm{Ti}_{3} \mathrm{Al} / \alpha_{2}-$ $\mathrm{Ti}_{3} \mathrm{Al}+\mathrm{Ti}_{2}(\mathrm{Cu}, \mathrm{Ni})+\mathrm{Ti}(\mathrm{Cu}, \mathrm{Ni})_{2} \mathrm{Al}$, sequentially from the periphery towards the centre of the interface. These layers are indicated by letters A, B and C in Fig. 2; the chemical compositions of the different reaction products detected at the interface are plotted in the isothermal sections presented in Fig. 3. Increasing the brazing temperature induces the formation of wider and Al-richer interfaces: (i) the extension of the interface increases from 111 to $257 \mu \mathrm{m}$ after joining at 980 and $1200^{\circ} \mathrm{C}$, respectively and (ii) when joining is performed at 1150 and $1200^{\circ} \mathrm{C} \mathrm{Ti}(\mathrm{Cu}, \mathrm{Ni}) \mathrm{Al}$ is detected at the centre of the interface (layer $\mathrm{C}$ ) instead of $\mathrm{Ti}_{2}(\mathrm{Cu}, \mathrm{Ni})$ and $\mathrm{Ti}(\mathrm{Cu}, \mathrm{Ni})_{2} \mathrm{Al}$. 


\section{References}

[1] E.A. Loria, Intermetallics 9 (2001) 997.

[2] T. Noda, T. Shimizu, M. Okabe et al, Mater Sci Eng A239-240 (1997) 613.

[3] S.L. Draper, D. Krause, B. Lerch et al, Mater Sci Eng A464 (2007) 330.

[4] P. Villars, Handbook of Ternary Alloy Phase Diagrams, ASM International, 1994.
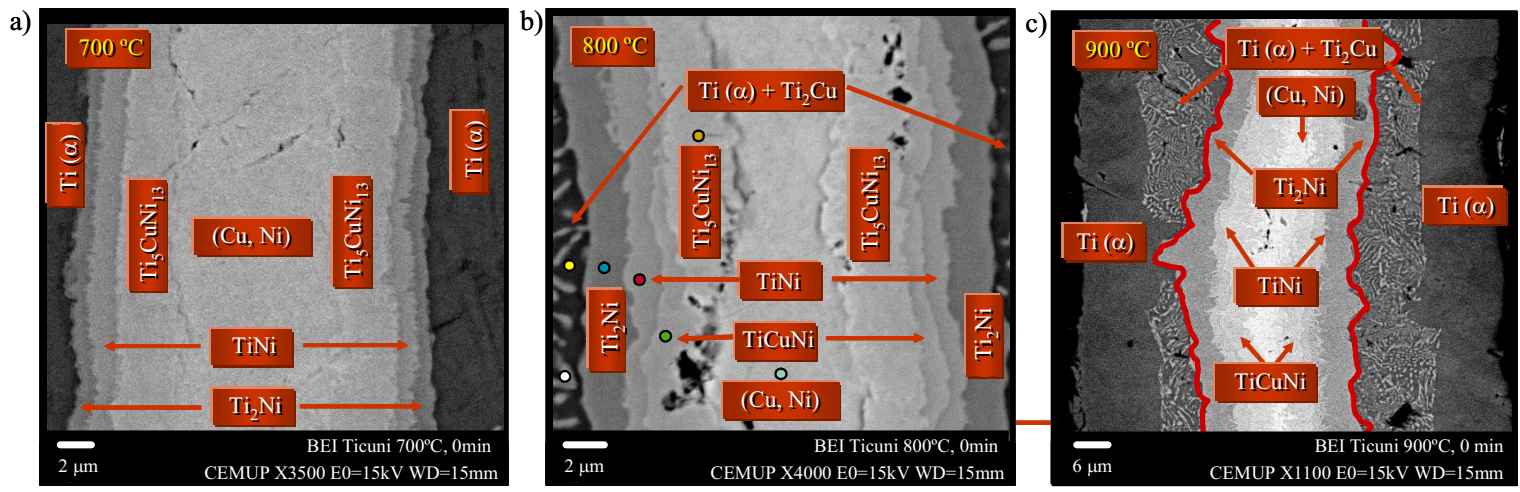

Figure 1 - Backscattered electron images (BEI) of the microstructure of the brazing alloy at room temperature, after heating to: a) $700^{\circ} \mathrm{C}$; b) $800^{\circ} \mathrm{C}$; c) $900^{\circ} \mathrm{C}$.
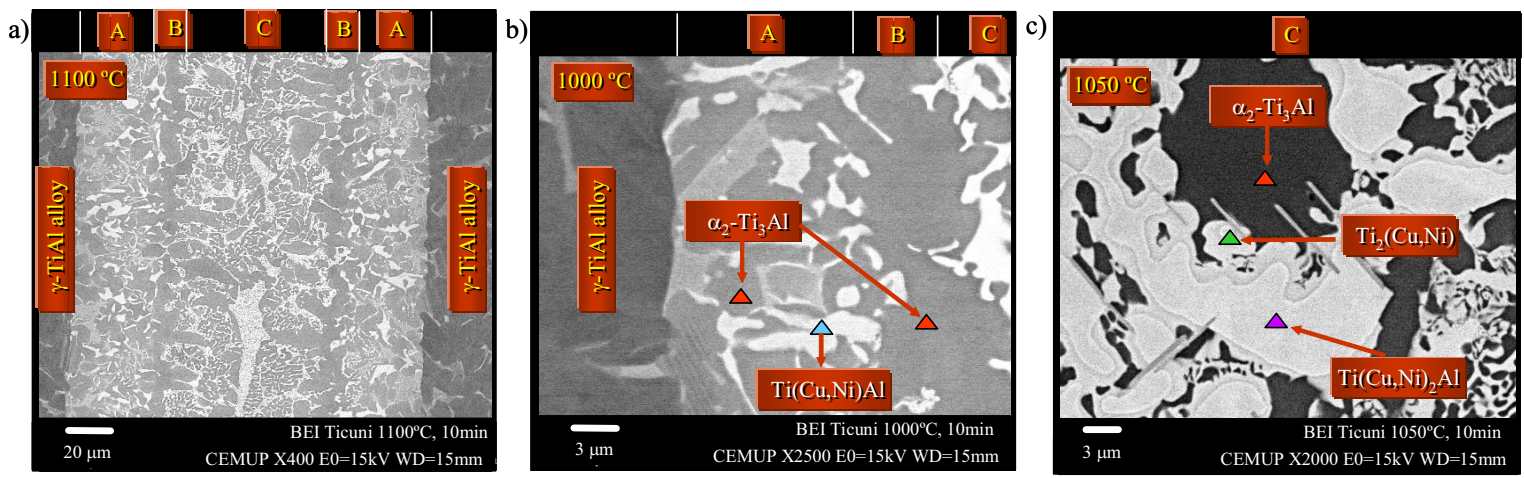

Figure 2 - BEI of the interface: a) global, after brazing at $1100^{\circ} \mathrm{C}$; b) magnification showing layers

$\mathrm{A}, \mathrm{B}$ and part of layer $\mathrm{C}$, after brazing at $1000^{\circ} \mathrm{C}$; c) layer $\mathrm{C}$, after brazing at $1050^{\circ} \mathrm{C}$.

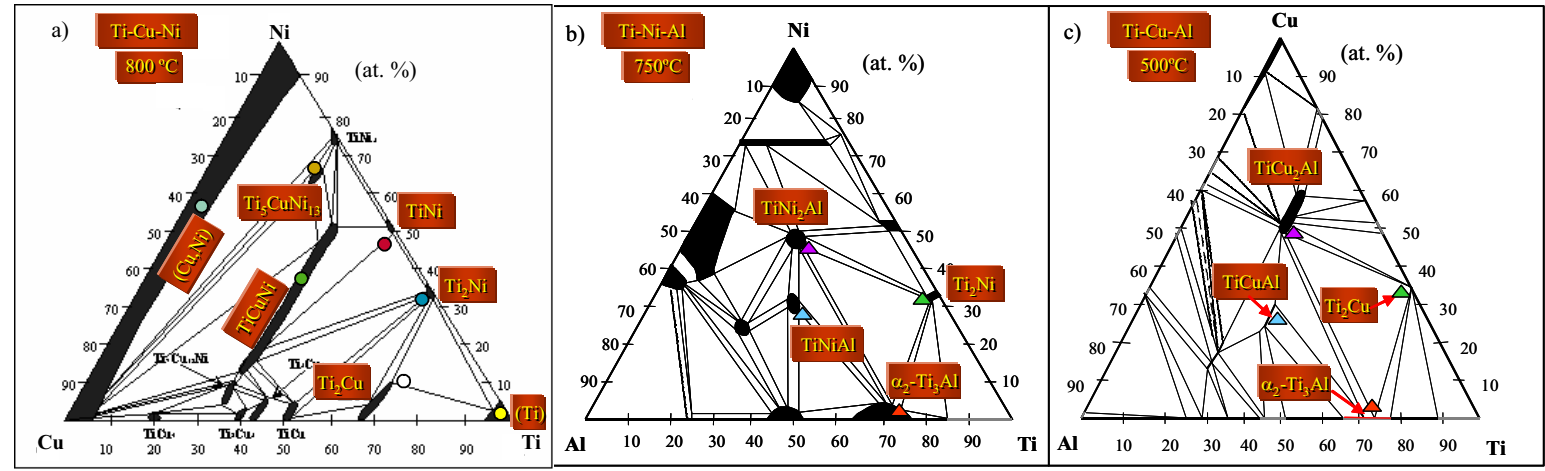

Figure 3 - Ternary isothermal sections, adapted from [4], where the compositions of some the reaction layers/products formed within the braze alloy and at the interface, respectively, are plotted:

a) braze alloy (see Fig. 1); b) and c) interface (see Figs. 2b) and 2c)). 